\title{
The change of organizational structure of higher education institutions in Hungary: a contingency theory analysis
}

https://doi.org/10.2478/irsr-2018-0009

Received: 23 August, 2017; Accepted: 6 March, 2018

\begin{abstract}
The management of higher education institutions has changed considerably over the last few decades. Most analyses in Europe usually focus on how the autonomy of institutions evolved, how the governance structure developed, and what kind of management roles and techniques appeared. Less attention has been paid to the change of formal organizational structure which, according to the contingency theory, has a significant impact on the efficiency and effectiveness of organizations. There is even less research on these issues in Central and Eastern European higher education. In this paper, the evolution of the organizational structure of Hungarian institutions is analyzed from a contingency theory perspective. The relationship between environmental factors (such as size, complexity, and stability of environment) and organizational responses (e.g., centralization and decentralization) is examined.
\end{abstract}

Keywords: higher education, governance, organizational structure, hungary, contingency theory, Central and Eastern Europe

\section{Introduction}

Over the last 30 to 40 years, European higher education has been in a state of permanent reform. The expansion of higher education, the appearance of new missions and tasks, the government-imposed funding reforms and the pressures from internationalization, globalization and technological development have all led to increasing

\footnotetext{
*Corresponding author: Gergely Kováts, Institute of Management and Center for International Higher Education Studies, Corvinus University of Budapest, Hungary, 1093 Budapest Fővám tér 8, E-mail: gergely.kovats@uni-corvinus.hu
}

complexity in higher education. All of these changes have also resulted in a continuous reform of the management of higher education institutions (HEIs) which cover their governance and their organizational structure - as well as the roles and responsibilities of actors.

The governance of higher education institutions includes the general responsibility, accountability and authority issues of owners, boards (consisting of different stakeholders), academic leaders, and the administration. The change of governance structure is closely related to the changing relationship between the state and institutions. One of the most characteristic changes in European higher education recently is a shift in the role of the state "from the government to governance" (de Boer et al. 2010:20), that is, how the state coordinates the higher education system. In general, bureaucratic coordination has been gradually replaced by indirect mechanisms such as incentive systems referred as 'steering from a distance' (de Boer et al. 2006). In many countries, this process is accompanied by the introduction of boards responsible for supervising the strategy and operation of institutions.

The organizational structure of higher education institutions refers to how responsibilities and spheres of authority are divided among academic and administrative units, and how coordination is realized among them. Notable examples are the emergence of new management units and positions or the growing importance of programs and projects as the basis of organizational structures.

Finally, the actual role of actors and its transformation focuses on the emergence (and the strengthening) of new management functions, tasks, and roles. The changing role of leaders could be an example: the shift in emphasis from meeting the expectations of colleagues to enforcing university-wide decisions (collegial vs hierarchical role); the appreciation of the administrative/management roles against the educational-researcher roles (which means having parallel careers becomes increasingly difficult); or the increasing demand to shift from operative to strategic focuses. 
While the development of university governance, as well as different leadership roles, are widely researched (see, for example, de Boer et al. 2010; Euridyce 2008; Dobbins and Knill 2009; Estermann and Nokkala 2009; Estermann et al. 2011 or Meek et al. 2010), the literature concerning the organizational structure of higher education institutions, in general, is sparse, with just a few exceptions (e.g. Lombardi et al 2002; Taylor 2006). Leisyte states, however, that "despite the extant literature on the transformation of the state and its steering capacity and reforms in CEE universities, there is limited analysis of the transformation that has taken place also at the organizational level.” (Leisyte 2014:97). Therefore, I will focus on how Hungarian higher education institutions evolved in the last three decades. For instance, what kind of new management units and positions appeared and how does the relationship between faculties and central administration changed (centralization versus decentralization)?

In the first section, I summarize the main points of contingency theory, which serves as a theoretical framework for my analysis. In the second part, I describe how the environment of Hungarian HEIs has changed since 1990. Some empirical evidence on the change of organizational structures is presented in the third section which also includes the analysis of changes. In the last section, I summarize and discuss results.

\section{Contingency theory}

Several organizational theories discuss how and why organizations change. It is the contingency theory which focuses primarily on the effect and change of formal structures, that is,

- the division of labor (what kind of units are defined, how tasks and responsibilities are distributed),

- the distribution of authority (e.g. the extent of centralization and decentralization, who decides on what etc.) and

- the applied coordination mechanisms (using regulations, plans, committees or other means to harmonize activities) (Bess - Dee 2007).

The main assumptions of the theory are the following (Kieser 1995):

- Formal structure significantly affects the efficiency of the organization.

- There is no structure which is effective in every environment (there is "no one best way").

- Organizations have to adapt their structure to the external and internal environment to be efficient or else their performance and competitiveness decrease. Therefore, changes in the structure aim to reduce the misfit between the environment and the organizations and reflect the efforts to increase efficiency. A persistent difference between two organizations can be explained by differences in their environment.

- Based on the results of empirical investigations it is possible to propose formal structures which could be efficient in a given environment.

The structure does not determine the behavior of organizational members, but it creates a general structure of incentives. Members' behavior serves as an intermediary between structure and performance. Figure 1 describes the main components of the theory and their relationship with each other.

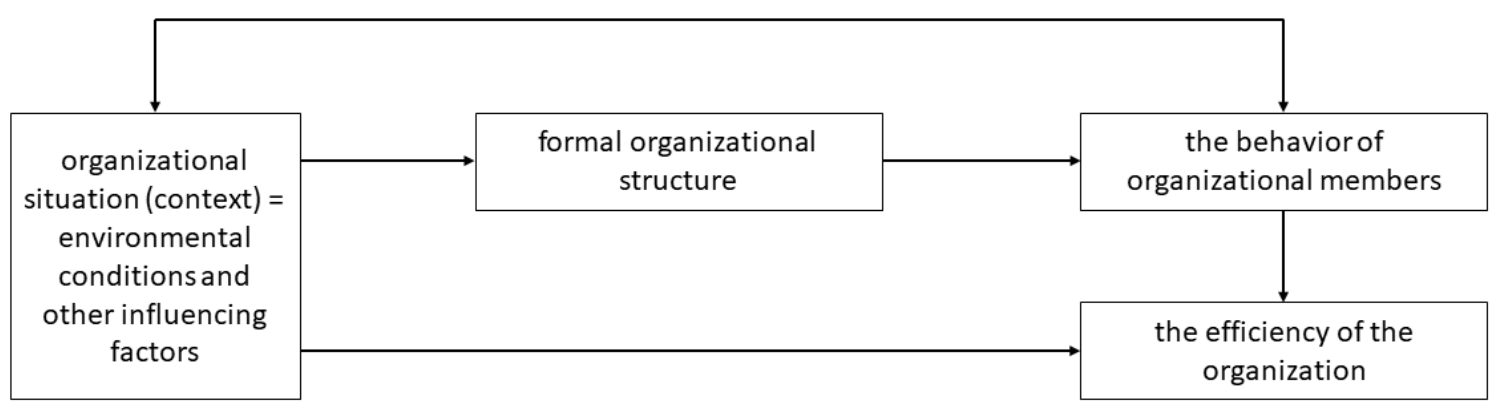

Figure 1: The main elements of the contingency theory, Source: Kieser 1995 
Researchers identified several situational (contextual) factors which affect organizational structures. Organizations can only influence these factors in the long run. We can distinguish internal and external factors (Kieser 1995). External factors are related to the external environment. Major external factors are the following:

- the development of different segments of the macro environment, such as the development of technology, the change of legal-regulatory environment, social and cultural changes, etc.

- task-related environment: complexity and dynamism of the sector (higher education industry), the level of competition in the sector, etc.

Internal factors are organization-specific characteristics which are difficult to change in a short time, such as

- the size of an organization,

- the profile of an organization,

- the technology of production.

Based on empirical investigations, researchers identified some general tendencies of an efficient way of organizing. For example, larger organizations are usually more differentiated (they have units with more specific responsibilities), more decentralized (units have authority to make some decisions) and the role of rules and planning is more typical than smaller ones (Bess - Dee 2007).

Contingency theory assumes that observed tendencies in organizational changes have to be an efficient way of organizing otherwise better solutions should have appeared and spread. Therefore, we should identify general trends of organizing and then find explanations of why these changes are efficient.

Therearetheories, however, thatcriticizethisapproach. According to the (neo)institutional organizational theory (Scott 2008), for example, organizations adapt solutions not just to increase efficiency, but also to gain legitimacy by meeting social expectations. To be legitimate, organizations sometimes adopt solutions which decrease efficiency. For instance, higher education institutions might create quality assurance units not to increase the quality of their education or research programs, but to project an image of a responsible, modern and innovative organization which follows current trends.

\section{The changing context of Hungarian higher education institutions}

Contingency theory identified those contextual factors which affect organizational structures.
In this section, I describe how some of these factors have evolved in Hungarian higher education since the change of the regime (1990), including the size of institutions, the changes of legal-regulatory environment, the complexity and stability of the environment and the profile of institutions. In the analysis, I focus mainly on public institutions which enrolled $87 \%$ of students in 2015/2016.

This long period is worth dividing into smaller sections. Although the change of governments or the introduction of crucial reforms could be used for division, I am going to use the acts of higher education for that purpose. Between 1985 and 2017 Hungary accepted acts on (higher) education four times, in 1985, in 1993, in 2005 and 2011.

\section{The size of higher education institutions}

Between 1990 and 2005, the number of students in the Hungarian higher education system quadrupled. The main source of the increase was the growing popularity of evening and distance learning. Tuition fees were introduced in 1996, and by 2005, the number of fee-paying students accounted half of the total number of students. After 2005 there has been a considerable decline in the number of students entering higher education. Although demographic trends contributed to this trend, the educational policy also had a strong influence on this decrease. For example, in 2012 the government started to decrease state-funded places in the most popular social science programs (such as law, business administration, etc.).

The growing number of students is accompanied by the restructuring of the network of HEIs. In the 1990s (as the legacy of the Soviet higher education system) Hungary had a highly fragmented higher education system with many specialized institutions. In 2000 the government created comprehensive institutions through forced mergers which were followed by several voluntary mergers. As a result, the number of state institutions dropped, and their average size increased significantly. Although this trend was slightly weakened by the decreasing number of students on the one hand, and by the government which created some highly specialized institutions through demergers after 2010, the average size remained significantly higher than in 1990.

It is worth noting that since the early 1990s churches and private organizations have been allowed to establish HEIs. The size of the private and church institutions remained quite small, except for two larger church 
Table 1: Institutes, faculties, teaching staff and student numbers in Hungary 1990-2015

\begin{tabular}{|c|c|c|c|c|c|c|c|c|c|c|}
\hline \multirow{2}{*}{$\begin{array}{l}\text { Academic } \\
\text { year }\end{array}$} & \multirow{2}{*}{$\begin{array}{l}\text { Overall } \\
\text { number of } \\
\text { students }\end{array}$} & \multicolumn{3}{|c|}{ State institutions } & \multicolumn{3}{|c|}{ Church institutions } & \multicolumn{3}{|c|}{ Private institutions } \\
\hline & & $\begin{array}{l}\text { Number of } \\
\text { institutions }\end{array}$ & $\begin{array}{l}\text { Number } 0 \\
\text { students }\end{array}$ & $\begin{array}{l}\text { fAverage } \\
\text { size of } \\
\text { institutions }\end{array}$ & $\begin{array}{l}\text { Number of } \\
\text { institutions }\end{array}$ & $\begin{array}{l}\text { Number of } \\
\text { students }\end{array}$ & $\begin{array}{l}\text { Average } \\
\text { size of } \\
\text { institutions }\end{array}$ & $\begin{array}{l}\text { Number of } \\
\text { institutions }\end{array}$ & $\begin{array}{l}\text { Number of } \\
\text { students }\end{array}$ & $\begin{array}{l}\text { Average } \\
\text { size of } \\
\text { institutions }\end{array}$ \\
\hline $1990 / 91$ & 108376 & 66 & 107607 & 1630 & 10 & 550 & 55 & 1 & 219 & 219 \\
\hline $1995 / 96$ & 195586 & 58 & 177482 & 3060 & 28 & 9055 & 323 & 4 & 9049 & 2262 \\
\hline $2000 / 01$ & 327289 & 30 & 283970 & 9466 & 26 & 17590 & 677 & 6 & 25729 & 4288 \\
\hline $2005 / 06$ & 424161 & 31 & 366797 & 11832 & 26 & 24078 & 926 & 14 & 33286 & 2378 \\
\hline $2010 / 11$ & 361347 & 29 & 314363 & 10840 & 26 & 20551 & 790 & 14 & 26433 & 1888 \\
\hline $2015 / 16$ & 295316 & 30 & 256630 & 8554 & 22 & 22151 & 1007 & 14 & 16535 & 1181 \\
\hline $2016 / 17$ & 287018 & 29 & 249152 & 8591 & 22 & 22197 & 1009 & 14 & 15669 & 1119 \\
\hline
\end{tabular}

Source: Educational Authority; the average size is the author's calculation

institutions and a private one with 5-10 thousand students each (as of 2016).

\section{Legal-regulatory environment and the autonomy of institutions}

Changes in organizational structures are shaped by regulations. Some of these regulations force institutions to adopt particular solutions, while others empower them to find those structural configurations which suit their needs. The concept of institutional autonomy in general and organizational autonomy, in particular, could be used to characterize the extent to which the legalregulatory environment restricts/enables institutions to shape their organizational structures. Unfortunately, the measurement of institutional autonomy started only in the mid-2000s (e.g., Esterman - Nokkala 2009, Esterman et al. 2011) so it is not adequate to depict the changes that have occurred since the 1990s.

Therefore, I am going to illustrate the change of legalregulatory environment through an example of how the foundation and operation of faculties were regulated.

In the 1985 Act on education, new faculties could be established only by the Ministerial Council on the proposition of a minister. (It is also worth mentioning that even the establishment of departments required ministerial approval.) The 1990 amendment of the act required Ministerial Council approval for the foundation of the faculties of non-state institutions as well. The governance of faculties (i.e. the composition and authority of faculty councils) was also strictly regulated.

Although the 1993 Act on higher education stated that "higher education institutions [...] develop their own organization," it also provided that "the university is divided into faculties and other comprehensive organizational units." As faculties were listed in a government decree, a government decision was still required for the establishment of faculties of state institutions. At first, non-state institutions were only obliged to notify the government about the establishment of faculties, but an amendment in 1996 extended the act of recording faculties in the government decree to the private and church-owned institutions as well.

The Higher Education Act of 2005 extended institutional autonomy in developing their own organizational structures. The law mentions the faculty as only a possible form of organizing educational activities suggesting that other alternatives exist. The decision of how to govern faculties (or other units) was completely left to the institutions. The listing of faculties in government decree was also abolished. At the same time, another government decree defined the minimum criteria for establishing faculties in detail (the faculty had to have a certain number of students and lecturers, and it had to offer degrees in at least two cycles). However, the monitoring of fulfilling these criteria was quite light and after 2009 was completely discontinued.

In 2011 a new Act of Higher Education was adopted, which reinforced faculty structure once again. The existence of at least three university faculties was required for the granting of a university status. To have economies of scale, university faculties had to meet certain criteria such as an adequate number of academics, proportion of senior academics and student-teacher ratio. The Act did not regulate the internal modus operandi of faculties. In 2015 these expectations were deleted from the Act, and other regulations were introduced.

Until 2015 the rector was the sole chief executive of the institutions. In 2015 a dual executive structure was introduced in which the budget and administration is managed by the so-called chancellor, while the rector is responsible only for academic staff and related issues. The chancellor has equal rank to the rector; by law, the 
chancellor can represent the institution and has veto power over budgetary issues. The chancellor is appointed by the prime minister and supervised by the government. The introduction of the chancellor system resulted in a considerable decrease of the organizational and financial autonomy of institutions (Pruvot - Estermann 2017).

To sum up, at the beginning of the 1990s the legalregulatory environment was quite restrictive which limited the organizational autonomy of HEIs. However, the level of autonomy gradually increased even if institutions were sometimes required to adopt particular solutions, for example, to set up quality assuarance systems or introduce governance mechanisms such as boards. In general, regulations became quite permissive until 2011 and provided more opportunity for institutions to define their own structure. After 2011, however, this trend turned back, and the environment became more restrictive once again than in the previous years.

\section{The complexity of environment and the profile of organizations}

The complexity of the environment of higher education institutions can be defined as the number of factors institutions should take into consideration to make decisions (Bess - Dee 2007). The level of complexity is influenced by several factors. The first one is the number of stakeholders because the more stakeholders an institution has, the more complex the web of interests is. Complexity is also affected by the relative weight of each stakeholder. If an institution depends heavily on one stakeholder (e.g. the government), it results in a less complex environment. Finally, the number and heterogeneity of activities also have a role here because the diversity of stakeholders of an institution is in direct relationship with the diversity of its activity profile.

How has complexity changed over time in Hungarian higher education? With the increase in demand (student numbers) the diversity of educational programs also increased both on the system and institutional level. On the one hand, new levels of education appeared, such as higher-level vocational training, specialized postgraduate education, and $\mathrm{PhD}$ programs. On the other hand, the number of programs started to proliferate at each level, which from time to time triggered the effort of governments to standardize and make the program structure more transparent (i.e., less complex) (Derényi 2009; Berács et al. 2017).

Research has also gained more importance. Universities traditionally emphasize research, but with the possibility to participate in international (European) research programs (FP7, H2020), there is more incentive to move from small-scale "little science" to "big science." Colleges were usually teaching-only institutions in the 1990s, but their aspiration to become a university (the "academic drift") gradually forced them to incorporate research into their activity profile (Bander 2012). These efforts were officially recognized in 2015 when most colleges were transformed into universities of applied sciences. Since then applied research has been expected from them and officially became part of their mission.

Finally, the third mission has become more important at least in rhetoric. According to an analysis of the mission statements and websites of institutions (conducted in 2011), social responsibility (together with education) became the most important task of institutions (Bander 2012). This change represents the modifying social contract that institutions should transform themselves from "ivory towers" to "lighthouses" (Hrubos 2012).

Although this evidence is far from complete, all of them suggest that institutions have been facing a much more complex environment than 30 years ago.

With regard to the profiles, in the Soviet era, Hungarian higher education was highly fragmented as institutions were over-specialized and had a very narrow profile. Their most important stakeholder was the state as it regulated and funded them directly. The environment was simple for institutions.

By the end of the 1990s however, specialized institutions were merged into comprehensive ones. The new institutions had a much wider profile (and therefore more stakeholders) on the one hand and higher internal heterogeneity (diversity) on the other. In this period the role of state changed as indirect governing mechanisms and funding methods spread. For example, formula funding was introduced (1996) or the direct governmental allocation of state-funded student places was replaced by a more competitive one (2005). The importance of other stakeholders also increased with the appearance of new funding sources (e.g. the introduction of tuition fees in 1996, EU grants, etc.). All this resulted in a more complex environment for institutions. Although the role of the state was reinforced after 2011 that decreased the complexity of the environment, the overall level of complexity remained high because other stakeholders (local governments, firms, fee-paying students, funding agencies, etc.) preserved their importance. 


\section{The stability of environment}

The stability of environment can be characterized by the number and frequency of radical changes which are affected by the (lack of) possibility to anticipate the direction of changes (Bess - Dee 2007). For example, how frequently does the state change regulations? How frequently do HEIs (competitors) change their strategy forcing other institutions to adapt? In other words,, what is the overall level of competition?

One notable attribute of post-socialist countries is that all the reforms which took place gradually in Western European countries from the 1980s onwards started simultaneously after the change of the regime. This resulted in a permanent reform process and an unstable environment. The growing dynamics (or instability) of the environment is reflected in Hungarian higher education. There were four Acts of higher education between 1990 and 2017 which were amended more than 130 times. While the Act of 1985 was amended once or twice a year on average while it was in effect, the Act of 2011 has been modified more than seven times per year. Many of the acts and amendments contained radical policy changes (Polónyi 2015).

Why does the number of amendments increase over time? One possible reason is the growing regulatory attitude of governments. The direct form of governance requires more regulations especially in an environment of growing complexity.

Another important aspect of the dynamics of the environment is the level of competition which depends on the number of suppliers, the level of demand and the form of funding.

First, until 2005 the higher education system was binary having only universities and colleges. They have different missions, they offered different degrees, and they were treated differently with regard to funding. Still, the academic drift was high, and the two types gradually converged into one another. After the introduction of the two-cycle system (in 2005) steps were taken towards a unitary system, making it possible for colleges to become universities if they met certain criteria. One of the criteria was to offer master and doctoral programs resulting in increased competition at these levels as well. In 2015 a new type of institution (university of applied sciences) was created, and all colleges (except for two small institutions) were transformed into universities of applied sciences in 2016.

Second, during the expansion of higher education, student preferences leaned towards social sciences, business and law. As the entry barrier in these fields is very low (no need for significant investments in technology and infrastructure, only in human terms), a growing number of institutions started to offer programs in these fields. In 1990 four institutions offered a degree in law, and six in economics or business administration. By 2000 their number increased to 7 and 22 respectively. Although student numbers and state-funded places decreased significantly by 2015, the number of HEIs offering degrees in these fields increased further to 8 (law) and 28 (business and management).

This process is hastened by the institutional mergers as the economies of scale through offering new programs is higher in larger institutions than in smaller ones. Many private institutions, the establishment of which was allowed from the early 1990s (Szemerszki 2005), also offered programs in these fields and they were entitled to state funds if they enrolled state-funded students.

The increase of suppliers did not necessarily lead to higher competition (except for some geographical areas) during the expansion period. Later, however, when demand for higher education started to decline in 2005, competition became fierce because institutional funding depended mainly on the number of students. The competition was also enhanced by the changing allocation of state-funded places. Before 2005, the ministry allocated state-funded places to institutions and educational programs. In 2005 a competition-based

Table 2. Acts on higher education in Hungary

\begin{tabular}{lllll}
\hline $\begin{array}{l}\text { Act on higher edu- } \\
\text { cation }\end{array}$ & $\begin{array}{l}\text { Number of months in effect until } \\
\text { the acceptance of the new act }\end{array}$ & $\begin{array}{l}\text { Number of years in effect until } \\
\text { the acceptance of the new act }\end{array}$ & $\begin{array}{l}\text { Total number of } \\
\text { amendments }\end{array}$ & $\begin{array}{l}\text { Amendments / years in } \\
\text { effect }\end{array}$ \\
\hline $1985-1993^{*}$ & 99 & 8,25 & 12 & 1,5 \\
$1993-2005$ & 149 & 12,42 & 37 & 3,0 \\
$2005-2011$ & 72 & 6,00 & 42 & 7,0 \\
$2011-$ & $68^{\star *}$ & $5,67^{\star *}$ & 43 & 7,6 \\
\hline
\end{tabular}

* This is an Act of education which contains the regulation of elementary and higher education

** Number of months/years until August 2017

Source: Based on Polónyi 2015 
Table 3. The number of Hungarian Students in UK higher education institutions

\begin{tabular}{llll}
\hline Academic year & First-year students & Other students & Total \\
\hline $2008 / 09$ & 1100 & 1020 & 2120 \\
$2009 / 10$ & 1195 & 1170 & 2365 \\
$2010 / 11$ & 1165 & 1310 & 2475 \\
$2011 / 12$ & 1155 & 1455 & 2610 \\
$2012 / 13$ & 1180 & 1525 & 2705 \\
$2013 / 14$ & 1480 & 1615 & 3100 \\
$2014 / 15$ & 1535 & 1950 & 3485 \\
$2015 / 16$ & 1680 & 2295 & 3975 \\
\hline
\end{tabular}

Source: Data provided by Higher Education Statistical Agency (HESA). Data request number: 52756

allocation of undergraduate places was introduced where only the best students were granted state funded places and the institution to which these students had been accepted received the subsidy for state-funded students. The remaining students had to pay tuition fees. However, in 2012 this allocation mechanism was replaced by the previous one.

Increasing competition led to the increase of students' bargaining power on the one hand, and the search for new students on the other. Some of the most prestigious institutions started to reinforce their international orientation to be able to attract more international students whose number almost doubled between 2005 and 2016: according to official statistics, the number of international students was 3310 in 1990, 11783 in 2001, 14491 in 2005 and 26682 in 2016.

Qualifications recognized by Hungarian authorities can be substituted by foreign degrees. The competitiveness of foreign institutions depends on the difficulty of qualification recognition, the availability, and affordability of foreign institutions and the level of difficulty involved in enrolling in Hungarian and foreign institutions. Foreign institutions have been permitted to offer educational programs since the early 1990s. In August 201723 foreign institutions were registered in Hungary ${ }^{1}$.In addition, the globalization of higher education and the restrictive policy of the Hungarian government after 2012, which focused on decreasing the number of state-funded student especially in social sciences, made many institutions in Europe more attractive for Hungarian students. In the UK, for example, the number of Hungarian students increased from 2120 to 3975 between 2008/2009 and 2015/2016 with a steeper increase in first-year students after 2012.

1 https://www.oktatas.hu/felsooktatas/kozerdeku_adatok/felsooktatasi_adatok_kozzetetele/felsooktatasi_intezmenyek/engedellyel_ mukodo_kulfoldi_intezmenyek
According to OECD statistics, Austria, Germany, Denmark and the UK were the most attractive countries in 2013 and 2014 (OECD 2017). It is also worth noting that the implementation of the Bologna process made the recognition of foreign qualifications much easier. These factors increase the competition in Hungarian higher education.

In summary, how has the stability of the environment developed in the last 25-30 years? There were several radical changes in regulations in the period, but the pace of change accelerated over time. Between 1996 and 2011 competition-enhancing tools were gradually introduced, but the competition was tempered by the abundant number of students until 2005. The number of students started to decline in 2005, and by 2011 public funding and the number students had decreased considerably, leading to increased competition, which peaked between 2005 and 2011. Although competition remained significant after that, it became less transparent - as state-funded places are directly allocated by the ministry to institutions and programs. The significance of foreign institutions increased over time especially after 2005 and 2011.

\section{Hypotheses}

The following table summarizes how the environment of Hungarian HEIs has changed over time. By using the denomination of "low," "medium" etc., I wish to picture the tendency of change as well as the relative extent of the given environmental factor.

Based on this analysis and the results of contingency theory some hypotheses can be proposed:

H1. An increasing number of activities in a more dynamic environment lead to increasing decentralization of core activities (teaching and research). 
Table 4. The change of higher education environment in Hungary

\begin{tabular}{|c|c|c|c|c|}
\hline & before 1993 & 1993-2005 & 2005-2011 & 2011- \\
\hline avg. size of institutions & low & medium & high-medium & medium \\
\hline autonomy of institutions & low & medium & medium-high & medium \\
\hline (permissiveness of regulations) & & & & \\
\hline complexity of environment & low & medium & high & medium-high \\
\hline dynamics of environment / level of competition & low & medium & high & medium-high \\
\hline $\begin{array}{l}\text { number and heterogeneity of activities pursued by } \\
\text { institutions }\end{array}$ & low & medium & high & high \\
\hline
\end{tabular}

Table 5. The number of faculties in Hungarian HE

\begin{tabular}{|c|c|c|c|c|c|c|c|c|c|c|}
\hline & 1987 & 1997 & & & 2009 & & & 2016 & & \\
\hline Maintainer* & $\mathbf{S}$ & $\mathbf{S}$ & C & $\mathbf{P}$ & $\mathbf{S}$ & C & $\mathbf{P}$ & $\mathbf{S}$ & C & $\mathbf{P}$ \\
\hline $\begin{array}{l}\text { Universities without faculties (including univ. of } \\
\text { applied sciences) }\end{array}$ & 2 & 2 & 3 & 0 & 4 & 3 & 2 & 8 & 3 & 3 \\
\hline $\begin{array}{l}\text { Universities with faculties (including univ. of } \\
\text { applied sciences) }\end{array}$ & 17 & 19 & 2 & 0 & 14 & 2 & 0 & 18 & 2 & 1 \\
\hline number of faculties & 52 & 71 & 5 & 0 & 106 & 9 & 0 & 123 & 8 & 2 \\
\hline Colleges without faculties & 35 & 35 & 24 & 6 & 5 & 20 & 13 & 3 & 16 & 10 \\
\hline Colleges with faculties & 0 & 0 & 0 & 0 & 6 & 0 & 0 & 0 & 1 & 0 \\
\hline number of faculties & 0 & 0 & 0 & 0 & 22 & 0 & 0 & 0 & 3 & 0 \\
\hline Total number of institutions & 54 & 56 & 29 & 6 & 29 & 25 & 15 & 29 & 22 & 14 \\
\hline $\begin{array}{l}\text { Total number of institutions without faculties + } \\
\text { number of faculties }\end{array}$ & 82 & 106 & 32 & 6 & 137 & 32 & 15 & 134 & 30 & 15 \\
\hline Total number of faculties & 52 & 71 & 5 & 0 & 128 & 9 & 0 & 123 & 11 & 2 \\
\hline
\end{tabular}

* $S=$ State institutions; $C=$ Church institutions; $P$ = Private institutions

Source: Own calculations from the official higher education statistical reports of 1987, 1994, 2009 and 2016.

We can assume that in in a rapidly changing environment less time is provided for making a decision. According to contingency theory, in ,a dynamic, complex environment (...) an organic, highly departmentalized structure is likely to be effective. (...) An organic design is needed to keep pace with external change. Not only are expectations and resources shifting, but they are also highly differentiated. Universities have a diverse set of expectations for teaching, research, and public service. (...) These institutions need a large number of departments to address the multiplicity and variety of external demands" (Bess and Dee 2007:148).

H2. The increase of size leads to increasing specialization and bureaucratization of institutions, that is, the number and presence of non-academic units increase.

Contingency and system theory have at least two explanations for that. First, in larger systems (organizations) the demand for some administrative and support services is higher, therefore creating organizational units dedicated specifically to these services is efficient. Second, in larger systems, personal coordination is partially replaced by impersonal rules, regulations, plans and incentive structures designed by the administration. This leads to increased bureaucracy and higher demand for administrative services (Kieser 1995).

H3. A more complex environment increases the centralization of administrative activities.

Burton Clark argues in his influential book about entrepreneurial universities that larger institutions in complex environment face 'demand overload': "The university-environment relationship is characterized by a deepening asymmetry between environmental demand 
and institutional capacity to respond" (Clark 1998:xvi). A more decentralized and differentiated structure of basic units can be capable of meeting increasing and diverse demands (see H1). But such a structure also requires a strengthened 'administrative steering core', because better coordination and special expertise is needed to manage more differentiated organizations. A strengthened steering core can provide "the institution a greater collective ability to make hard choices among fields of knowledge, backing some to the disadvantage of others" (Clark 1998:138).

\section{Changes in the formal structure of institutions}

\section{The number of faculties}

The first hypothesis can be verified by observing how the number of faculties evolved. As faculties responsible for organizing education and research activities in their disciplines, which is usually supplemented by increasing authority over human resources and budgeting, their growing number necessarily lead to increased decentralization.

The number of faculties increased from 52 to 136 between 1987 and 2016. Part of this increase can be due to the merger processes in 2000 when around 25 independent institutions were merged as faculties into larger institutions. The rest of the increase is the consequence of the more permissive regulation and other environmental effects (expansion, competition, Bologna process, etc.). In line with $\mathrm{H} 1$, the number of faculties in public institutions decreased from 2009 to 2016. During this period the number of students also fell. But in a 25 -year period, the overall trend is the growing number of faculties.

The structural consequence of this trend is the increasing internal complexity and heterogeneity of institutions, in which a rector usually has to supervise faculties in quite different disciplines. The more diverse faculties are, the more decentralization is probable in issues like education, research, and budgets. This trend is in line with the increasing dynamism of environment which requires more careful attention from deans. These results confirm H1.

An additional organizational response to the growing heterogeneity and complexity can be the reinforcement of formal rules and structures, that is, increasing the relative importance of administration and management functions

Table 6. The development of central administration in a Hungarian public university

\begin{tabular}{|c|c|c|c|c|}
\hline & 1994 & 2001 & 2009 & 2017 \\
\hline $\begin{array}{l}\text { Approximate number } \\
\text { of students }\end{array}$ & 4100 & 11800 & 17400 & 11400 \\
\hline IT Services & IT Center & IT Service Center & IT Service Center & IT Service Center \\
\hline Registry & Central Registry Office & Directorate of Education & $\begin{array}{l}\text { Central Registry and } \\
\text { Information Office }\end{array}$ & Central Registry Directorate \\
\hline International activities & $\begin{array}{l}\text { sOffice for International } \\
\text { Relations }\end{array}$ & International Directorate & International Office & $\begin{array}{l}\text { Directorate of International Relations and } \\
\text { Innovation }\end{array}$ \\
\hline $\begin{array}{l}\text { Communication \& } \\
\text { Marketing }\end{array}$ & - & Communications Office & Communications office & Directorate of Communications \\
\hline Career counseling & - & Career Office & Career Office & - \\
\hline Student Counseling & - & - & $\begin{array}{l}\text { Office of Student Coun- } \\
\text { seling }\end{array}$ & Office of Student Counseling \\
\hline Quality Assurance & - & - & $\begin{array}{l}\text { Office for Quality Deve- } \\
\text { lopment }\end{array}$ & $\begin{array}{l}\text { 1. Directorate of Strategy and Quality } \\
\text { Development } \\
\text { 2. Office for Quality Assurance and } \\
\text { Process Management }\end{array}$ \\
\hline Corporate relations & - & $\begin{array}{l}\text { Office of Corporate } \\
\text { Relations }\end{array}$ & $\begin{array}{l}\text { Office of Corporate } \\
\text { Relations }\end{array}$ & - \\
\hline Tendering & Office for Tendering & Office for Tendering & Office for Tendering & Office for Tendering \\
\hline Strategy development & & - & - & $\begin{array}{l}\text { Directorate of Strategy and Quality Deve- } \\
\text { lopment }\end{array}$ \\
\hline Research support & $\begin{array}{l}\text { Science Management } \\
\text { Unit }\end{array}$ & - & - & Directorate for Research \& Development \\
\hline
\end{tabular}


regarding staff, resources, etc. This leads us to the second hypothesis.

\section{The extent of central administration}

Thesecond hypothesisfocus on the extent of differentiation of administration. This assumption could be tested by scrutinizing the evolution of central administration within institutions. Unfortunately, only scarce data are available regarding the size of administration and the structure of institutions in the 1990s and early 2000s.

For example, the number of staff in administration could be used as one input to test H2. Gornitzka and his colleagues analyzing staff numbers of two decades of the Norwegian higher education system found that staff performing managerial duties (from which they exclude simple clerical tasks) increased faster than the number of the academic staff (Gornitzka, Kyvik, et al. 1998; Gornitzka - Larsen 2004). However, official statistics regarding the number of administrative employees in Hungarian HEIs have been available only since 2003. By that time, most institutions reached their current size. It is not surprising therefore that the proportion of non-academic employees changed little between 2003 and 2016. Among public institutions, the average proportion was $62.8 \%$ (2003) and $60.4 \%$ (2016). If we omit institutions with hospitals, the proportion is $47.7 \%$ and $45.2 \%$ respectively.

Because of the lack of proper data, we can rely on fragmented evidence and observations to verify or invalidate $\mathrm{H} 2$.

First, the following table illustrates the development of the central administration of a Hungarian public institution since 1994. The table shows whether there were units dedicated to specific tasks and if so, what was their name at that time.

The table provides a good illustration that as size increases, administration becomes more professional and more differentiated. Tasks which were covered informally or as part of a larger responsibility during one period became the responsibility of new units in the next one. As a result, fulfilling that task became more standardized and regulated.

The evolution of central administration in one institution cannot be generalized to the whole higher education system, but based on the illustration and other observations we can make assumptions as to how and why central administration developed as the size of institutions increased.

In the 1990s student exchange and teacher mobility programs became available and popular, international offices and exchange offices started to spread in the 1990s.
In institutions where offices with such responsibility had existed before, the function changed. Instead of organizing (and controlling) international trips (which lose importance as traveling abroad become possible without limitations) the main task was to handle international (exchange) relations, to prepare and support Hungarian students for travelling abroad (e.g. Erasmus program) and to recruit and support foreign students to study in Hungary.

Tender offices also appeared in this period reflecting the growing number of possibilities to apply for developmental funds (PHARE, World bank funds) and research grants.

The development and growth of IT infrastructure were also the outcomes of the 1990s. The importance and size of IT Service Centers increased, but they usually carry out support activities, and application and software development has been gradually outsourced and bought from specialized service providers (Mogyorósi 2009).

From the beginning of the 2000s, the number of students started to stagnate and fall in many institutions. Competitiveness and income generation became prominent raising the importance of image, reputation, student services, and third-stream income activities. Also, efforts to increase the efficiency of resource utilization and allocation became more frequent.

Therefore this is the period when PR and marketing units shaping institutional image appeared or existing communication units put more emphasis on external communication and a coherent, professional appearance of their institutions.

In addition to one-time gifts (such as laptops) provided at the first registration, new permanent student services appeared such as learning and psychological counseling, career counseling, mediation between students and employers (organization of internships, advertising jobs, etc.) and services for alumni students. Most of them aimed to increase the attractiveness of the institution.

Most offices of quality development were established around 2005 because the 2005 Act on Higher Education required institutions to employ quality assurance mechanisms and most institutions fulfilled their requirement by creating quality management units. EU and governmental development programs also encouraged institutions to set up such units.

Few institutions also established corporate relationship offices as an independent unit or as part of career offices. Their responsibility was not exclusively the management of relationships, but fundraising as well. Non-profit ventures and spin-off enterprises founded by higher education institutions also play a role in this, but 
Table 7. Number of institutions with units dedicated to specific tasks in 2012

\begin{tabular}{lll}
\hline Task & Number of institutions & Percentage of institutions \\
\hline $\begin{array}{l}\text { Educational services (e.g., registry office, Directorate for education), teaching \& } \\
\text { learning centers }\end{array}$ & 19 & $83 \%$ \\
Tender/Grant application and monitoring, project management, innovation, techno- 18 & $78 \%$ \\
logy transfer & 17 & $74 \%$ \\
International relations & 15 & $65 \%$ \\
Quality assurance & 12 & $52 \%$ \\
Career services, graduate tracking, alumni & 12 & $52 \%$ \\
Communication, PR, marketing & 7 & $30 \%$ \\
Strategy, institutional development & 6 & $26 \%$ \\
Research management & 5 & $22 \%$ \\
Student counseling & 3 & $13 \%$ \\
Corporate relations & 3 & \\
\hline
\end{tabular}

Source: own calculation based on bylaws of 23 public institutions

Table 8. The responsibility of vice rectors in 2012 and 2017

\begin{tabular}{lllll}
\hline Task & $\mathbf{2 0 1 2}$ & $\mathbf{2 0 1 7}$ \\
\cline { 2 - 5 } & Number of institutions & $\begin{array}{l}\text { Percentage of institu- } \\
\text { tions }\end{array}$ & $\begin{array}{l}\text { Number of insti- Percentage of insti- } \\
\text { tutions }\end{array}$ & \multicolumn{2}{c}{$\begin{array}{l}\text { tutions } \\
\text { Number of analyzed institutions }\end{array}$} & 23 & & 21 \\
Average number of vice rectors & 2,9 & $74 \%$ & 2,9 & $48 \%$ \\
General deputy & 17 & $87 \%$ & 10 & $81 \%$ \\
Science/research/innovation & 20 & $65 \%$ & 17 & $81 \%$ \\
Education & 15 & $43 \%$ & 17 & $19 \%$ \\
Strategy/development & 10 & $39 \%$ & 4 & $48 \%$ \\
International relations & 9 & $22 \%$ & 10 & $10 \%$ \\
Public relations / Communication & 5 & $22 \%$ & 2 & $29 \%$ \\
Other & 5 & 6 & \\
\hline
\end{tabular}

Note: vice-rectors responsible for more than one fields are counted in each field.

Source: own calculation based on bylaws of public institutions.

they also promote cooperation with the business sector and offer better conditions to spend money acquired from competitive tenders.

Many infrastructure and facility management activities were outsourced as part of the rationalization efforts. As a result, the role of facility management units changed considerably. Instead of providing maintenance and security services, their main responsibility became to monitor outsourced activities (Czinderi 2009). Planning, tendering and asset management still play an important role in their activity.

The following table contains the results of the analysis of the by-laws of 23 public institutions. The by-laws were from 2012 which was the end of the most competitive and complex period of the Hungarian higher education system. The table shows the number of institutions with units dedicated to specific tasks.

Having a specific unit for organizing educational processes, grant application, international relations, and QA were the most widespread, while units focusing on research management and corporate relations are quite rare. The spread of each task reflects the relative importance of these tasks.

All in all, as the size of institutions increased, HEIs seemed to develop many administrative and service functions and units. The lack of accurate data makes it impossible to assess the effect of falling student numbers on administration after 2005.

\section{Complexity and central administration}

The third hypothesis focuses on the relationship between complexity and central administration. I also analyzed the responsibilities of vice rectors and found that in 2012 ten institutions had a vice rector responsible for strategy or development, and seven institutions had units with that kind of primary responsibility (three institutions had both) suggesting that a complex and dynamic environment requires increased strategic capability. Between 2012 and 2017 the autonomy of institutions decreased and their 
dependence on the government increased resulting in decreasing competition and complexity. The repetition of the analysis of the by-laws of 21 institutions in 2017 revealed that only four institutions had a vice rector for strategy, and four institutions had a unit explicitly dedicated to strategy (two had both).

One possible interpretation of this result is that in a less complex environment where the importance of one stakeholder (the government) increases significantly, there is less need for planning and coordination. Although this is not very strong evidence, it nevertheless is in line with $\mathrm{H3}$.

The possible effects of the newly introduced chancellor system are also worth some remarks. The chancellor system contributes to the centralization of administrative tasks because the authority of deans over the administrative staff working on the faculty decrease. According to a survey about the chancellor system which was conducted in 2015 among academic leaders, the weight of faculties will decrease in institutions in the future and centralization will increase (Kováts 2016). This change is not because of the increasing complexity of an uncertain environment, but because the environment became less permissive and more regulative than before.

\section{Reflections}

The goal of this paper was to study how organizational structures have evolved in Hungarian HEIs since the change of the regime. The analysis was based on contingency theory, which explains organizational developments by the changes of external and internal environment.

Based on the analysis, we can state that the complexity and dynamics of the environment increased considerably in the last 30 years. Institutional autonomy which is necessary to adapt to the changing context also increased, but to a lesser extent. The size of organizations (in terms of student numbers) also grew.

Organizational responses seem to be clear: both the academic and administrative structure became more differentiated. Many new faculties and administrative units were established leading to more standardized processes and more bureaucratic way of operation. While the creation of new faculties resulted in the decentralization of the academic structure, the administration became more centralized because most administrative units were placed in the center so that they can monitor and provide services to all faculties. Therefore, it is not surprising that tensions between academic and administrative units as well as between faculty and institutional-level leaders also raised.
Although the growing importance of administration helped the institutionalization of their activities and roles, this process is far from completion. In many institutions as well as in official statistics, administrative staff is called 'non-academic' staff or 'other' staff which suggests that they are inferior to academics irrespective of their actual contribution to the operation of the institution (see also Gornitzka and Larsen 2004). It seems that the increase of administration's role in the operation is only slowly followed by the increase of their recognition. Members of the academic staff often explain the lack of recognition by stating that "the administration is not a service provider yet, only a bureau” or "the administration is not professional enough" as can frequently be heard in many Hungarian institutions.

Another interesting phenomenon is how the role of rector has changed over time. If responsibilities for academic issues are delegated to deans in large institutions, what is the role of the rector? In addition to ceremonial and representative duties, and coordinating and harmonizing faculty initiatives, the rector's main duty was to manage and supervise administration especially in large institutions. With the appearance of chancellors, however, rectors lose this responsibility, which can press them to increase their activity in academic issues (or fulfill mainly ceremonial roles). As a result, decentralization of academic issues might decrease in the future.

Notes: Official statistics on Hungarian higher education is available on the website of the Educational Authority at https://www.oktatas.hu/felsooktatas/kozerdeku_ adatok/felsooktatasi_adatok_kozzetetele/felsooktatasi_ statisztikak

Acknowledgement: The author is supported by the Janos Bolyai Research Fellowship of the Hungarian Academy of Sciences. The financial support is gratefully acknowledged.

Author contributions: G.K. is accountable for all aspects of the work.

\section{References}

Bander, K. (2012): Vállalt küldetések az intézményi honlapok alapján. (Institutional missions based on their websites). In: Hrubos, Ildikó (ed.) Elefántcsonttoronyból világítótorony (From ivory tower to lighthouse). Budapest: Aula Kiadó, pp. 72-102. http://mek.oszk.hu/11300/11397/11397.pdf

Berács J., Derényi A, Kádár-Csoboth, P., Kováts G, Polónyi I, Temesi J. (2017) Hungarian Higher Education 2016 - strategic 
progress report. Corvinus University of Budapest, Centre for International Higher Education Studies, Budapest. http://nfkk. uni-corvinus.hu/index.php?id=63342\&L=1

Bess, James L. - Dee, Jay R. (2008). Understanding college and university organization: Theories for effective policy and practice. Sterling, Va.: Stylus.

Boer, H. de - Jongbloed, B. - Enders, J. - File, J. (2010). Progress in higher education reform across Europe. Governance Reform. Volume 1: Executive Summary main report. Research Report. CHEPS, Twente. http://doc.utwente.nl/88695/

Boer, H. de - Leisyte, L. - Enders, J. (2006). The Netherlands. 'Steering from a distance.' In: Kehm, B. M. - Lannzendorf, U. (eds): Reforming University Governance. Changing Conditions for Research in Four European Countries. Bonn, Lemmens. pp. 59-96.

Clark, B. (1998). Creating entrepreneurial universities. Organizational pathways of transformation. London: IAU Press \& Pergamon.

Czinderi, G (2009). Müszaki folyamatok menedzsmentje kiszervezés az üzemeltetésben (Management of maintenance and operation processes - outsourcing in operations). In: Hrubos, I. - Török, I. (eds.). Intézményi menedzsment a felsöoktatásban. Szemelvények kiemelt témakörökben. (Institutional management in higher education.). Budapest: Müegyetem Kiadó. p. 275-290 http://www.fgsze.hu/ kiadvanyok/imf1_konyv.pdf

Derényi, A. (2009) A magyar felsőoktatás átalakulása 1989 és 2008 között (The transformation of Hungarian higher education between 1989 and 2008.) In: Drótos, Gy., Kováts, G. (eds.) (2009). Felsőoktatás-menedzsment. (Higher education management) Budapest: Aula Kiadó, 31-62

Dobbins, M., Knill, C. (2009) Higher Education Policies in Central and Eastern Europe: Convergence toward a Common Model? Governance, 22(3), 397-430

Estermann, T., Nokkala, T. (2009): University Autonomy in Europe I., EUA, Brussels.

Estermann, T., Nokkala, T., Steine, M. (2011): University Autonomy in Europe II. The Scorecard. EUA, Brussels. http://www.eua.be/ Libraries/publications/University_Autonomy_in_Europe_II_-The_Scorecard.pdf?sfvrsn $=2$

Eurydice (2008): Higher Education Governance in Europe. Policies, structures, funding and academic staff. Eurydice, Brussels.

Gornitzka, Å., Kyvik, S., Larsen, I. (1998). The bureaucratisation of universities. Minerva 36: 21-47.

Gornitzka, Å., Larsen, I. (2004). Towards professionalisation? Restructuring of administrative work force in universities. Higher Education 47: 455-471.

Hrubos, Ildikó (ed.) Elefántcsonttoronyból világítótorony (From ivory tower to lighthouse). Budapest: Aula Kiadó.
Kieser, A. (1995): Kontingenciaelmélet (Contingency theory) In: Kieser, A. (ed.)(1995) Szervezetelméletek (Organizational theories). Aula Kiadó, Budapest.

Kováts G. (2012) The Position and the Role of the Dean in the Transforming Higher Education System, PhD dissertation. Corvinus University of Budapest, Budapest. http://phd.lib. uni-corvinus.hu/674

Kováts, G. (ed.)(2016): A kancellári rendszer bevezetése a magyar felsőoktatásban. Tapasztalatok és várakozások (The introduction of the chancellor system into the Hungarian higher education. Experiences and expectations.) Center for International Higher Education Studies, Corvinus University of Budapest, Budapest.

Leisyte, L. (2014): The Transformation of University Governance in Central and Eastern Europe: its Antecedents and Consequences. Leadership and Governance in Higher Education, Volume No. 1. pp. 96-118

Lombardi, J.V., Craig, D. D., Capaldi, E. D., Gater, D. S. (2002) University Organization, Governance, Competitiveness. The Center for Measuring University Performance. http://mup.asu. edu/UniversityOrganization.pdf

Meek, L., Goedegebuure, L., Santiago, R., Carvalho, T. (eds) (2010): The Changing Dynamics of Higher Education Middle Management. Springer, Dordrecht.

Mogyorósi, J. (2008). Felsőoktatási informatikai rendszerek menedzsmentje. (IT management in higher education) In: Hrubos, I. - Török, I. (eds.). Intézményi menedzsment a felsöoktatásban. Szemelvények kiemelt témakörökben. (Institutional management in higher education.). Budapest: Müegyetem Kiadó. p p. 257-274 http://www.fgsze.hu/kiadvanyok/imf1_ konyv.pdf

OECD (2017): Share of international students enrolled by country of origin. http://dx.doi.org/10.1787/eag-data-en

Polónyi I. (2015): A hazai felsőoktatás-politika átalakulásai (The changes of Hungarian higher education). Iskolakultúra. 25(5-6), 3-14. http://real.mtak.hu/34801/1/01.pdf

Pruvot, E., Estermann, T. (2017): University Autonomy in Europe III. The Scorecard 2017. European University Association, Brussels.

Scott, W Richard (2008). Institutions and organizations. 3rd ed. Thousand Oaks (Ca.): Sage Publication.

Szemerszki, M. (2005): A magánfelsőoktatás kialakulása Magyarországon. (The emergence of private higher education in Hungary). PhD Dissertation. Corvinus University of Budapest, Budapest. http://phd.lib.uni-corvinus.hu/695/1/Szemerszki_ Mariann.pdf

Taylor, J. (2006) Big is beautiful. Organisational Change in Universities in the United Kingdom: New models of Institutional Management and the Changing Role of Academic Staff, Higher Education in Europe, 31, 251-273. 